\title{
Distribution and Redistribution of Pancreatic Islet Cell Surface Antigen Reactive with Islet Cell Surface Antibody in the Rat
}

\author{
H. Ohgawara, ${ }^{1}$ T. Okano, ${ }^{2}$ K. Kataoka ${ }^{3}$ and Y.Sakurai ${ }^{2}$ \\ ${ }^{1}$ Diabetes Centre, ${ }^{2}$ Institute of Medical Engineering, and ${ }^{3}$ Heart Institute of Japan, Tokyo Women's Medical College, Tokyo, Japan
}

\begin{abstract}
Summary. Antigens on the rat pancreatic islet cell surface were redistributed into patch and cap formation when the cells were incubated in the presence of the phosphodiesterase inhibitor, 3-isobutyl-1-methylxanthine, in tissue culture medium 199 for $24 \mathrm{~h}$, before addition of rat pancreatic islet cell surface antibody. In contrast, if the cells were cultured in tissue culture medium 199 supplemented with glucose $(5.5$ or $16.7 \mathrm{mmol} / 1$ ) and $10 \%$ heat-inactivated fetal calf serum with-
\end{abstract}

out 3-isobutyl-1-methylxanthine, cap formation was not detectable. These results suggest that mobile antigen on the surface of pancreatic B cells can be induced to aggregate into patch and cap formations during conditions of increased cellular metabolism.

Key words: Rat, islet cell surface antigen, immunobeads, patch and cap formation.
The possibility that immunological reactions may be involved in the pathogenesis of insulin-dependent diabetes has been supported by the demonstration of islet cell cytoplasmic antibodies [1,2] and islet cell surface antibodies (ICSA) [3] in the sera from insulin-dependent diabetic patients. Cytoplasmic islet cell antibodies and ICSA are most prevalent at the onset of the disease and decrease thereafter [4]. The role of these antibodies in the pathogenesis of diabetes and the nature of the antigens are still unknown.

Scanning electron microscopy has proved to be a useful technique for studying cell surface architecture and has gained wide application in cell biology. The surface architecture of the islet cell was found to change showing an increased number of villi or blebs after incubation in the presence of a high concentration of glucose [5].

The present investigation was designed to study the binding of antibodies to rat pancreatic islet cell surface antigen and the effect of the phosphodiesterase inhibitor, 3-isobutyl-1-methylxanthine (IBMX) on the distribution of antigen using scanning electron microscopy and visualizing bound antibodies with immunobeads or indirect immunofluorescence.

\section{Materials and Methods}

\section{Preparation of Dispersed Islet Cells}

Adult rat pancreatic islets were prepared under sterile conditions by collagenase digestion of the pancreas [6]. Islets were separated from the digests by discontinuous Ficoll gradient centrifugation, and washed by repeated low speed centrifugation in tissue culture medium 199 (TCM 199), before being selected individually by micropipette. The islets were placed in TCM $199(10 \mathrm{ml})$ with IBMX $(0.1 \mathrm{mmol} / \mathrm{l})$, collagenase $(30 \mathrm{mg})$, hyarulonidase $(20 \mathrm{mg})$ and ethyleneglycol-bis- $(\beta$ aminoethyl ether) $\mathrm{N}, \mathrm{N}^{\prime}$-tetra acetic acid $(1.0 \mathrm{mmol} / \mathrm{l})$ for $30 \mathrm{~min}$ at $37^{\circ} \mathrm{C}$ in an atmosphere of $5 \% \mathrm{CO}_{2}$ and $95 \%$ air. The islet suspensions were then kept for $24 \mathrm{~h}$ in plastic petri dishes containing TCM 199 , further supplemented with $10 \%$ heat-inactivated fetal calf serum, penicillin $(400 \mathrm{U} / \mathrm{ml})$, glucose $(5.5 \mathrm{mmol} / 1)$ and IBMX $(0.1 \mathrm{mmol} / 1)$ [7]. Finally, after resuspension in TCM 199 the islets were disrupted into free cells by mechanical shaking. The dispersed cells were washed by centrifugation in Krebs-Ringer-Henseleit-buffer. Viability of the cells as determined by Trypan blue exclusion was approximately $95 \%$.

\section{Preparation of Immunobeads}

A $10 \%$ suspension of polystyrene latex particles $(0.5 \mu$ diameter, Dow Chemical, Midland, Michigan, USA) in $0.2 \mathrm{~mol} / \mathrm{l}$ phosphate buffered saline (PBS, pH 7.4, $0.1 \mathrm{ml}$ ) was mixed with goat anti-rabbit-IgG (32 $\mathrm{mg}$ in $0.2 \mathrm{~mol} / 1 \mathrm{PBS}, 20 \mathrm{ml}$ ) and incubated at room temperature for $6 \mathrm{~h}$. The adsorption under these conditions was shown to be adequate for a monolayer formation of $\operatorname{IgG}$ on the polystyrene surface [8]. The beads adsorbed with anti-rabbit-IgG, designated as immunobeads, were separated by centrifugation $(5000 \mathrm{rev} / \mathrm{min} ; 20 \mathrm{~min})$, washed three times in PBS $(0.2 \mathrm{~mol} / \mathrm{l})$ and resuspended in $20 \mathrm{ml}$ of the same buffer.

\section{Incubation of Cell Suspensions}

The dispersed islet cells were incubated at $37^{\circ} \mathrm{C}$ for $24 \mathrm{~h}$ in TCM 199 containing either glucose $(5.5$ or $16.7 \mathrm{mmol} / \mathrm{l})$ with or without IBMX $(0.1 \mathrm{mmol} / \mathrm{l})$ in an atmosphere of $5 \% \mathrm{CO}_{2}$ and $95 \%$ air. Aliquots $\left(10^{4}\right.$ cells) in Krebs-Ringer-buffer $(100 \mu l)$ were then incubated at $37^{\circ} \mathrm{C}$ for 5 min either with or without $1.0 \%$ formaldehyde. 


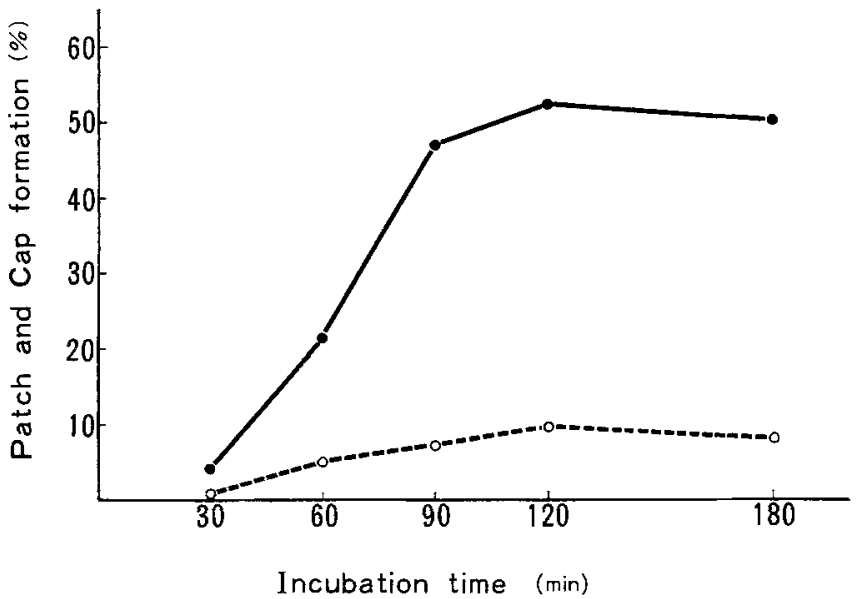

Fig. 1. Time couse of ligand-dependent patch and cap formation. After prolonged incubation in TCM 199 supplemented with or without 3-isobutyl-1-methylxanthine $(0.1 \mathrm{mmol} / 1)$, cells were incubated with islet cell surface antibodies at $37^{\circ} \mathrm{C}$ for $30-180 \mathrm{~min}$ in an atmosphere of $5 \% \mathrm{CO}_{2}$ and $95 \%$ air, then ligand-dependent patch or cap formation of surface IgG was determined. $-\ldots, O-\mathrm{O}_{-} \mathrm{O}$ : cells were cultured in the medium with and without 3-isobutyl-1-methyl xanthine for periods up to $24 \mathrm{~h}$ respectively. $>200$ cells were observed at each time point shown

\section{Fluorescence Microscopy}

The cells were washed with Krebs-Ringer buffer and incubated at $37^{\circ} \mathrm{C}$ in an atmosphere of $5 \% \mathrm{CO}_{2}$ and $95 \%$ air for $30-180 \mathrm{~min}$ in TCM $199(100 \mu \mathrm{l})$ containing glucose $(16.7 \mathrm{mmol} / \mathrm{l})$ and either anti-rat ICSA positive sera (dilution 1:100) or normal rabbit serum (1:100 dilution). The cells were then washed with Krebs-Ringer buffer and incubated for $60 \mathrm{~min}$ at $37^{\circ} \mathrm{C}$ in fluoresceinated goat anti-rabbit-IgG (1:10 dilution), and finally washed with cold Krebs-Ringer buffer and mounted without fixation. Using an Olympus fluorescence microscope (Model BH-RFC), photographs were taken with Kodak Tri-X film (exposure time $30 \mathrm{~s}$ ).

The rabbit anti-rat islet cell serum, extensively adsorbed with rat spleen cells, was kindly given by Dr. A. Lernmark (Hagedorn Reseach Laboratory, Copenhagen, Denmark); its preparation and characterization for ICSA have been described elsewhere [9].

\section{Scanning Electron Microscopy}

Islet cells in suspension were incubated at $37^{\circ} \mathrm{C}$ for $90 \mathrm{~min}$ in KrebsRinger buffer $(100 \mu \mathrm{l})$ with anti-rat ICSA positive sera (dilution 1:100), or with normal rabbit serum (dilution 1: 100). After washing by centrifugation in Krebs-Ringer buffer, the cells were resuspended in PBS containing anti-rabbit-IgG immunobeads $(100 \mu \mathrm{l})$ at $37^{\circ} \mathrm{C}$ for $60 \mathrm{~min}$ and again washed in cold Krebs-Ringer buffer. The cells were fixed at $4^{\circ} \mathrm{C}$ for $24 \mathrm{~h}$ with $1.25 \%$ glutaraldehyde in physiological saline, washed by centrifugation in Krebs-Ringer buffer and adsorbed onto poly (L-lysine) -coated glass coverslips [10].

The cells on the coverslips were rapidly frozen at $-70^{\circ} \mathrm{C}$ and freeze-dried for $48 \mathrm{~h}$. The coverslips were mounted on sample stages and coated with gold in a vacuum. The cells were examined in a Hitachi-Akashi MSM-101 scanning electron microscope.

\section{Results}

Islet cells, incubated with rabbit anti-rat ICSA positive serum at $37^{\circ} \mathrm{C}$ for $30-180 \mathrm{~min}$, were fixed and labelled with fluoresceinated goat anti-rabbit IgG. Patch and cap formation was determined as a function of time after the TCM 199 was supplemented with the antibodies. The ligand-dependent patch and cap formation reached a plateau within $90 \mathrm{~min}$ (Fig. 1). Approximately $50 \%$ of the cells formed patches after incubation with 3-isobutyl-1-methylxanthine, and occasional caps were also observed during the 3 - $h$ incubation period. IBMX induced patch and cap formation at the same rate whether the cells were incubated with either low $(5.5 \mathrm{mmol} / \mathrm{l})$ or high $(16.7 \mathrm{mmol} / \mathrm{l})$ concentrations of glucose (data not shown). In contrast, when the cells were incubated for $24 \mathrm{~h}$ in a medium without IBMX, patch and cap formation was markedly reduced (Fig. 1). Cells which were incubated with normal rabbit serum instead of rabbit anti-rat ICSA positive serum at $37^{\circ} \mathrm{C}$ for $90 \mathrm{~min}$, showed neither patch nor cap formation. Fixation of cells in $1.0 \%$ formaldehyde inhibited redistribution of surface-bound fluorescent antibodies.

Figure 2 shows the differential mobilities of surface IgG observed on the islet cells incubated with IBMX and antibodies. During a 3-h incubation period, 30 cells were examined at $30,90,120$ and $180 \mathrm{~min}$. This procedure was repeated eight times. Almost all the cells showed a diffuse distribution of fluorescent $\mathrm{IgG}$ before starting the 3-h incubation period with ICSA. Patch and cap formation was observed during the incubation period with antibodies. When the cells were incubated in a medium without IBMX, patch and cap formation was markedly reduced.

The surface architecture of rat pancreatic islet cells undergoing patch and cap formation was studied in more detail by scanning electron microscopy (Fig. 3). During the 3-h incubation period with ICSA positive serum, surface microvilli on the islet cells were replaced by lamellae, and subsequently an almost completely smooth surface appeared. These cells were then labelled with immunobeads.

When the islet cells were incubated with normal rabbit serum instead of rabbit anti-rat islet cell surface serum, goat anti-rabbit IgG coated beads did not attach to the cells. The results shown in Figure 3 also suggest that goat anti-rabbit IgG immunobeads exert a stimulatory effect on patch or cap formation of related receptors.

\section{Discussion}

It is well known that lymphocyte surface immunoglobin can be redistributed into patch and cap formation, a phenomenon which is thought to require the cross-linking of receptors by the antibody [11-13]. We have reported here that rat pancreatic islet cell surface antigens can also be redistributed into patch and cap formations by binding with specific rabbit anti-rat ICSA after exposure of the cells to a medium containing IBMX for at least $24 \mathrm{~h}$. Maximum patch formation occurred within 90-180 min under these conditions. In the standard me- 


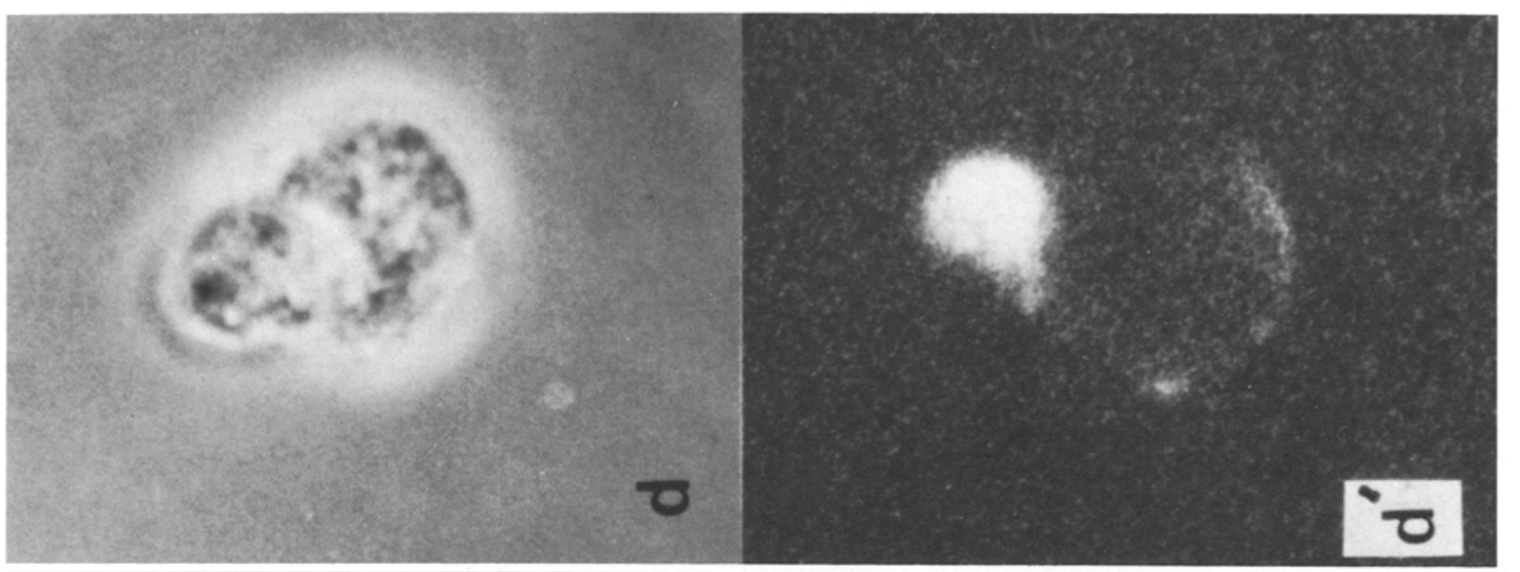

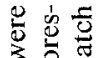
$\Rightarrow$ 늘 울 푸

E. 西 高文 焉记 금욤 这专

言菏

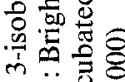
至 $\ddot{\bar{\theta}} \bar{g}$

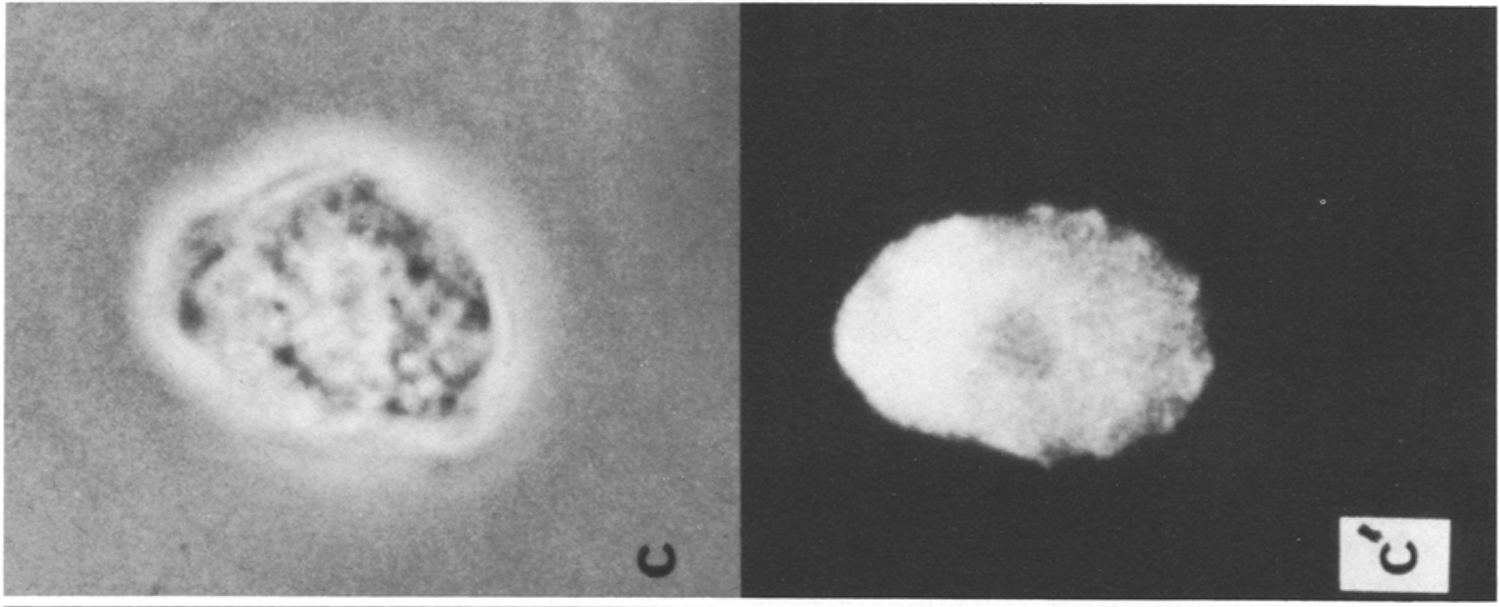

la $x$ 过

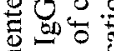

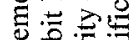

응

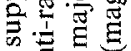

و

$\sum$ 突.

政

I

ธี

क

亏을

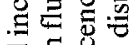

诺

ธี ช

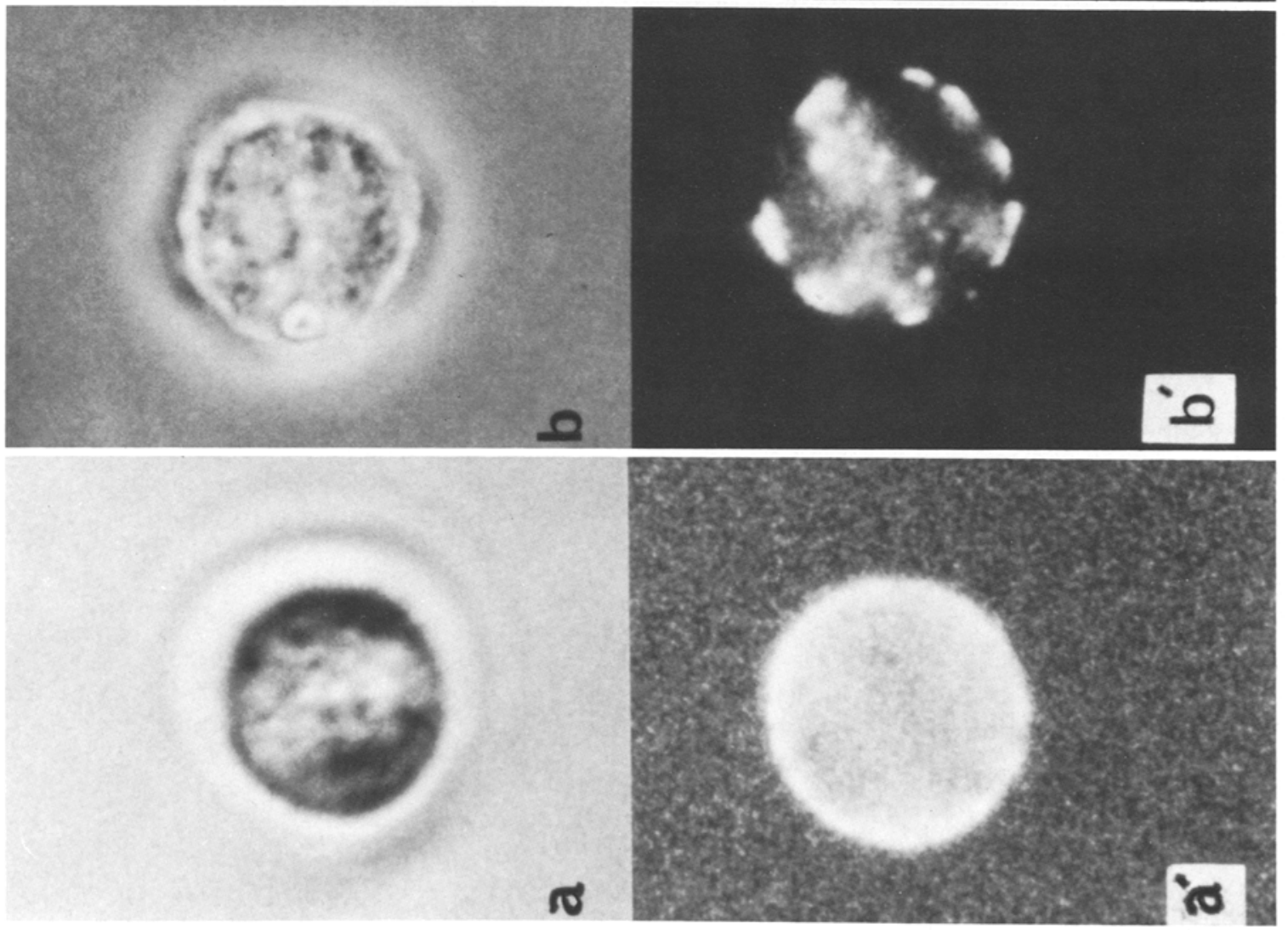

范心

可

․ㅗㅇ

뭉

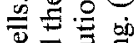

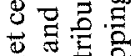

,

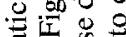

要这

흐은

F $\bar{\nu}=$

쥴류 है है

可

동

远园

㩆

농

60

80 \%

t를 을

4 \%

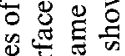

政

क्षे

웡

要造

중

항

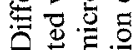

O

숭효

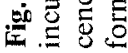



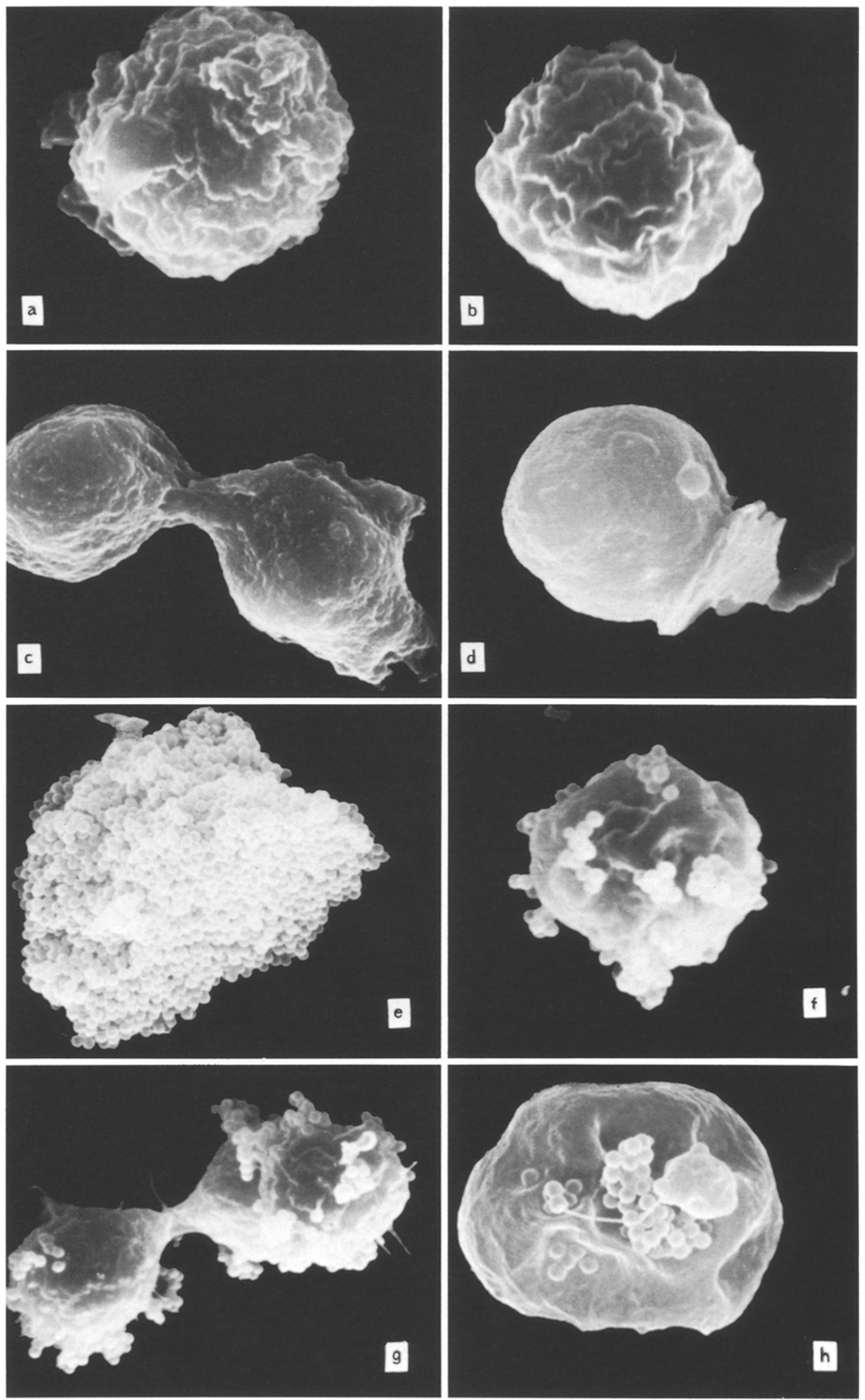

Fig. 3. After prolonged incubation in TCM 199 supplemented with 3-isobutyl-1-methylxanthine $(0.1 \mathrm{mmol} / \mathrm{l})$, the cells were incubated with islet cell surface antibody for $120 \mathrm{~min}$ as described in Fig. 1 and then labelled with anti-rabbit IgG immunobeads. (a-d) Control cells of the same incubation period fixed with glutaraldehyde before addition of anti-rabbit IgG immunobeads. During the incubation period the cell surface gradually developed lamellae $(\mathrm{a}-\mathrm{c})$ but later developed a smooth appearance $(\mathrm{d})$. (e-h) The distribution of immunobeads on an individual islet cell. Random distribution of immunobeads on an islet cell (e). Patchy distribution of immunobeads and lamellar-appearance of the cell surface ( $\mathrm{f}$, $\mathrm{g}$ ). Clearly aggregated beads showing cap formation on the cell and marked flattening of the cell surface $(h)$. Magnification: $(\times 9000) a, b, d, f, h$; $(\times 6300) \mathrm{c}, \mathrm{e}, \mathrm{g}$ 
dium without IBMX, ligand-dependent patch and cap formation was minimal.

The data in Figure 1 demonstrate the stimulatory effect of IBMX on the appearence of patch and cap formation on B cells. Before starting the 3 -h incubation period, almost all of the cells showed diffuse distribution of fluorescent IgG. Patch and cap formation occurred during the incubation with antibody. The possibility that lymphocytes were involved in the patch and cap formation was excluded as no formation was seen during the first $30 \mathrm{~min}$ of incubation. (Lymphocytes form patches and caps within 10-15 min of incubation with antibody.)

Patch and cap formation has been discussed in terms of interactions between surface receptors and cytoplasmic structure $[11,16,17]$. There is some evidence to suggest that cap formation involved a contractile system consisting of actin, myosin and regulating protein $[18,19]$. In several studies, it was reported that cap formation took place even in the absence of a specific ligand $[14,15]$, but we did not observe this in our study. In our experiments, we demonstrate that antibodies bound to the rat islet cell surface can redistribute into patch and cap formations. The patch formation was predominant on islet cells that reacted with ICSA. In particular, in the medium with IBMX, it occurred almost simultaneously to the addition of the ICSA positive sera.

It has been reported that microvilli are developed to a greater extent on metabolically inactive cells when compared with active cells [22,23], and also it was suggested that microvilli and lamellae may be composed mainly of microtubules and microfilaments [20, 21]. Yahara et al. reported that surface lamellae, not microvillae, are reponsible for the translocation of receptors during cap formation [24]. These observations imply that the islet cell surface possesses antigens which are able to move and that this mobility is stimulated by IBMX.

Acknowledgements. We thank Dr. I. Yahara, the Tokyo Metropolitan Institute of Medical Science, for his advice, and Dr. D. F. Steiner, the University of Chicago, for his critical reading of the manuscript. We are also thankful to Dr. A. Lernmark who kindly supplied us with the rabbit anti-rat islet cell positive serum.

\section{References}

1. Bottazo GF, Florin-Christensen A, Doniach D (1974) Islet cell antibodies in diabetes mellitus with autoimmuno polyendocrine deficiencies. Lancet 2: 1279-1283

2. MacCuish AC, Jordan J, Campbell CJ, Duncan LJP, Irvine WJ (1974) Antibodies to islet-cells in insulin-dependent diabetics with coexistent autoimmune disease. Lancet 2: 1529-1533

3. Lernmark $\AA$, Freedman $\mathrm{ZR}$, Hoffman C, Rubenstein AH, Steiner DF, Jackson RL, Winter RJ, Traisman HS (1978) Islet cell surface antibodies in juvenile diabetes mellitus. $N$ Engl J Med 299: $375-380$

4. Irvine WJ, Gray RS, McCallum CJ, Duncan LJP (1977) Clinical and pathogenic significance of pancreatic islet cell antibodies in diabetics treated with oral hypoglycaemic agents. Lancet 1 : 1025-1027

5. Lernmark $\AA$, Winbland B (1977) Scanning electron microscopy of surface change on dispersed pancreatic cells following stimulation of insulin release. Med Biol 55: 141-147

6. Lernmark $\AA$, Nathana A, Steiner DF (1976) Preparation and characterization of plasma membrane-enriched fractions from rat pancreatic islet. J Cell Biol 71: 606-623

7. Ohgawara H, Carroll R, Hoffmann C, Takahashi C, Kikuchi M, Labrecque A, Hirata Y, Steiner DF (1978) Promotion of monolayer formation in cultured whole pancreatic islets by 3-isobutyl1-methylxanthine. Proc Natl Acad Sci 75: 1897-1900

8. Sakurai Y, Akaike T, Kataoka K, Okano T (1980) Interfacial phenomena in biomaterial chemistry. In: Goldberg E, Nakajima A (eds) Biomedical polymers. Academic Press, New York, pp 335-379

9. Lernmark Å, Kanastuna T, Patzelt C, Diakoumis K, Carroll R, Rubenstein AH, Steiner DF (1980) Antibodies directed against the pancreatic islet cell plasma membrane. Diabetologia 19:445-451

10. Sanders SK, Alexander EL, Braylan RC (1975) A high-yield technique for preparing cells fixed in suspension for scanning electron microscopy. J Cell Biol 67: 476-480

11. Tayer RB, Duffus WHPH, Raff MC, De Petris S (1971) Redistribution and phagocytosis of lymphocyte surface immunglobulin molecules induced by anti-immunoglobulin antibody. Nature New Biol 233: 225-230

12. De Petris $S$ (1978) Distribution and mobility of plasma membrane components on lymphocytes in dynamic aspect of cell surface organization. In: Poste G, Nicolsen GL (eds) Cell surface review, vol. 3. North Holland, Amsterdam, pp 643-728

13. Schreiner GF, Unanue ER (1976) Membrane and cytoplasmic changes in B lymphocytes induced by ligand-surface immunoglobulin interaction. Adv Immunol 24: 34-165

14. Yahara I, Kakimoto-Sameshima F (1977) Ligand-independent cap formation: Redistribution of surface receptors on mouse lymphocytes and thymocytes in hypertonic medium. Proc. Natl Acad Sci $74: 5411-4515$

15. Schreiner GF, Braun J, Unanue ER (1976) Spontaneous redistribution of surface immunoglobulin in the motile B lymphocyte. $\mathrm{J}$ Exp Med 144: 1683-1688

16. De Petris S, Rafi MC (1972) Distribution of immunglobulin on the surface of mouse lymphoid cells as determined by immunoferritin electron microscopy: Antibody-induced, temperature-dependent redistribution and its implications for membrane structure. Eur J Immunol 2: 523-535

17. Loor F, Forni L, Pernis B (1972) The dynamic state of the lymphocyte membrane: factors affecting the distribution and turnover of surface immunglobulins. Eur J Immunol 2: 203-212

18. Gabbiani G, Chapnnier C, Zumbe A, Vassalli P (1977) Actin and tubulin co-cap with surface immunoglobulins in mouse lymphocytes. Nature 269: 687-698

19. Sundvist KG, Ehrnst A (1976) Cytoskeletal control of surface membrane mobility. Nature 264: 226-231

20. Puck TT, Waldren CA, Hsie AW (1972) Membrane dynamics in the action of dibutyl adenosine $3^{\prime}: 5$-cyclic monophosphate and testosterone on mammalians cells. Proc Natl Acad Sci 69: 1943-1947

21. Puck TT (1977) Cyclic AMP, the microtubulus-microfilament system, and cancer. Proc Natl Acad Sci 74: 4491-4495

22. De Petris S (1978) Preferential distribution of surface immunoglobulins on microvilli. Nature 272: 66-68

23. Loor F, Hagg, LB (1975) The modulation of microprojections on the lymphocyte membrane and the redistribution of membranebound ligands, a correlation. Eur J Immunol 5: 854-865

24. Yahara I, Kakimoto-Sameshima F (1979) Mechanism of translocation of microvilli accompanying cap formation of surface receptors. Cell Structure and Function. 4: 143-152

Received: 21 January 1982

and in revised form: 6 August 1982

Dr. H. Ohgawara

Diabetes Centre

Tokyo Women's Medical College

10 Kawada-cho, Shinjuku-ku

Tokyo, Japan 